\title{
Reproductive phenology and sharing of floral resource among hummingbirds (Trochilidae) in inflorescences of Dahlstedtia pinnata (Benth.) Malme. (Fabaceae) in the Atlantic forest
}

\author{
CAIO C.C. MISSAGIA ${ }^{1,3}$, FÁBIO C. VERÇOZA ${ }^{2}$ and MARIA ALICE S. ALVES ${ }^{3}$ \\ ${ }^{1}$ Programa de Pós-Graduação em Ecologia, Universidade Federal do Rio de Janeiro, \\ Ilha do Fundão, 21941-450 Rio de Janeiro, RJ, Brasil \\ ${ }^{2}$ Programa de Pós-Graduação em Ciências Biológicas (Botânica), Museu Nacional, Universidade Federal \\ do Rio de Janeiro, Quinta da Boa Vista, s/n, São Cristóvão, 20940-040 Rio de Janeiro, RJ, Brasil \\ ${ }^{3}$ Universidade do Estado do Rio de Janeiro, IBRAG, Departamento de Ecologia, \\ Rua São Francisco Xavier, 524, Maracanã, 20550-011 Rio de Janeiro, RJ, Brasil
}

Manuscript received on April 10, 2013; accepted for publication on January 17, 2014

\begin{abstract}
The purpose of this study was to investigate the reproductive phenology and sharing of floral resource (nectar) of Dahlstedtia pinnata (Benth.) Malme. (Fabaceae), endemic of Atlantic forest, among hummingbirds. For the phenology, we looked at the presence of reproductive structures in the plants, and for floral resource sharing, the frequency of potential pollinators and foraging behaviors were examined. This study was conducted in Pedra Branca State Park, in state of Rio de Janeiro, in a dense ombrophilous forest, between August 2010 and August 2011. Flowering occurred between December 2010 and March 2011, and fruiting between April and June 2011. Hummingbirds' foraging schedules differed significantly, with legitimate visits to the flowers occurring in the morning and illegitimate visits occurring during late morning and the afternoon. Five species visited flowers, three of which were legitimate visitors: Phaethornis ruber, P. pretrei, and Ramphodon naevius. Amazilia fimbriata and Thalurania glaucopis females only visited illegitimately. Phaethornis ruber robbed nectar (78\% of illegitimate visits, $\mathrm{n}=337)$. Ramphodon naevius, with a territorial foraging behavior and a body size bigger than that of other observed hummingbird species, dominated the floral visits, which suggests that $D$. pinnata is an important nourishing resource for this endemic bird of the Atlantic forest, currently globally categorized as Near Threatened.
\end{abstract}

Key words: floral theft, foraging behavior, ornithophily, pollination.

\section{INTRODUCTION}

The reproductive phenology of a plant species is the set of biological events frequently occurring related to their flowering or fruiting. Phenological events can be influenced by abiotic factors such as temperature and photoperiod (Talora and Morellato 2000) and by biotic factors such

Correspondence to: Maria Alice dos Santos Alves

E-mail:masaal@globo.com as pollinators (Levin and Anderson 1970), or influence the animal community, as in the activity of floral visitors (Heithaus 1979) and frugivores (Genini et al. 2009). Knowledge of the reproductive phenology of species is important to elucidate different aspects related to the dynamics of tropical ecosystems, such as the regeneration of natural environments and plant-animal interactions (Talora and Morellato 2000). 
Hummingbirds that belong to the Trochilidae family (subdivided into Trochilinae and Phaethornithinae) are endemic to the Americas and feed on floral nectar and small arthropods (Schuchmann 1999, Sick 1997). In exchange for feeding on nectar, the hummingbirds transport the plants' pollen grains between different flowers. This relationship is defined as pollination mutualism and ensures the gene flow in the plant population, seeing that this process can result in the pollination of the flower and consequently its fertilization ( $\mathrm{Hu}$ et al. 2008, Raven et al. 2007).

The term niche refers to the range of physical conditions a species can tolerate for its survival, as well as its role in the ecological system (Ricklefs 2010). In the case of hummingbirds, one of the key components of their niches is their role as pollinators of diverse botanical families (Rocca and Sazima 2008, Machado et al. 2007, Buzato et al. 2000, Bawa 1990). The species can overlap a small portion of their niches as to create a sharing of resources among species (Mendonça and Anjos 2005, Varassin and Sazima 2000, Stiles and Wolf 1970).

Different hummingbird species can pollinate the same species of plant as long as there is a sharing of the floral resource (Missagia and Verçoza 2011, Piacentini and Varassin 2007, Cotton 1998). The organization of the sharing among nectarivorous birds is determined by a number of factors, such as territorial behavior and the dominance hierarchy (Antunes 2003, Cotton 1998, Wolf 1978). The territorial species is aggressive and vigorously defends its resources against invaders, of which there can be many, leading to a great expenditure of energy that must be compensated by the quality of the resource (Carpenter et al. 1983, Feinsinger and Colwell 1978, Wolf 1978, Wolf and Hainsworth 1971). The dominance hierarchy is influenced by the species' size and aggressiveness (Loss and Silva 2005, Brown et al. 1978, Feinsinger 1978), reflecting a balance between the importance of a sought floral resource to a certain species and its ability to dominate the other species that utilize the same resource. Thus, the sharing of resources through the dominance hierarchy can avoid the direct competition between species, without the animal having to invest more time in foraging, in terms of territory defense (Linhart 1973, Wolf and Hainsworth 1971).

Dahlstedtia Malme. (Fabaceae) is a plant genus endemic to Brazil found only in the Atlantic forest biome (Teixeira and Gabrielli 2000). This genus is represented by only two species that do not occur in sympatry, $D$. pentaphylla (Taub.) Burk. and $D$. pinnata (Benth.) Malme. The species D. pinnata has only been registered in the states of Rio de Janeiro and São Paulo (Teixeira and Ranga 2004). Both species are shrubs with large, tubular flowers and striking coloring (Teixeira and Gabrielli 2000).

The interaction between $D$. pinnata and hummingbirds was previously registered by Missagia and Verçoza (2011) in the municipality of Rio de Janeiro, where they observed three hummingbird species visiting this plant's flowers: Ramphodon naevius (Dumont, 1818), Thalurania glaucopis (Gmelin, 1788), and Phaethornis ruber (Linnaeus, 1758). However, they did not conduct a quantitative study of the interactions at that time. The objective of the present study was to investigate the reproductive phenology of $D$. pinnata and to evaluate if hummingbird species share the floral resources (nectar) of this plant, taking into consideration the visitors' foraging behavior during the day.

\section{MATERIALS AND METHODS}

STUDY AREA

The study was conducted in Pedra Branca State Park (PEPB) in the Vargem Grande neighborhood of Rio de Janeiro. The park has a distribution of $12,500 \mathrm{Ha}$, encompassing the dense hillsides of the Pedra Branca mountain, located at an altitude of $100 \mathrm{~m}$ above sea level (SMAC 1998), between the coordinates: $22^{\circ} 50^{\prime}$ and $23^{\circ} 15^{\prime} \mathrm{S}$, and $43^{\circ} 20^{\prime}$ and $43^{\circ}$ 
40' W (Costa and Silva 2004). The vegetation of the study area corresponds to the Dense Ombrophilous Forest (IBGE 1992). The region's climate, according to the Köppen classification, is type Af. The average rainfall in the region is $1,187 \mathrm{~mm}$. The yearly average of the maximum monthly average temperatures is $26.1^{\circ} \mathrm{C}$, and the minimum monthly averages $20^{\circ} \mathrm{C}$ (Oliveira 2005).

\section{DATA COLLECTION}

In two transects of $500 \times 5 \mathrm{~m}\left(\mathrm{~S} 22^{\circ} 57^{\prime} \mathrm{S}\right.$ and $43^{\circ} 29^{\prime} \mathrm{W}$ ) established parallel to a preexisting trail in the area, 10 individuals of $D$. pinnata were individually marked and monitored between August 2010 and August 2011, in order to determine the reproductive phenology (the flowering and fruiting periods) and to identify floral visitors (Kearns and Inouye 1993).

Day-long expeditions were performed bimonthly during the vegetative period and every three days during the flowering period, for a total of 45 days. Observations were made during 50 minutes of each hour, between 06:00 and 11:50, and between 13:00 and 16:50, in only one individual of the plant per day, using the focal sampling method of individuals (Altmann 1974), for a total of 375 hours of focal observations. The observations were made using $8 \times 42 \mathrm{~mm}$ binoculars and the floral visitors were photographed. We recorded the frequency of the visits and determined the visitation rate $(\mathrm{T}=$ visits per hour) for each species of hummingbird visiting D. pinnata. Each approximation of a hummingbird where consumption of nectar took place was considered a visit, regardless of the number of flowers that were visited.

We took into consideration the legitimacy (when the bird body was in contact with the reproductive structures of the flower - stigma and anther) and the time of the flower visits, as well as the foraging behavior of the visiting species. The hummingbird species were categorized as territorial when they defended their resources exhibiting agonistic interactions, and categorized as trapliner foragers in the absence of territorial behavior, even though trapliners are defined by regular intervals of visits (Feinsinger and Colwell 1978, Wolf 1978). We can not affirm that those visits were made at regular intervals, because the birds were not individually marked, and for this reason we have decided to use the absence of territorial behavior to define trapliners.

We investigated whether body size (weight) of hummingbird species affected the dominance of a particular species over another (Brown et al. 1978). Measurements were obtained through existing literature (Dunning Jr 2008).

\section{DATA ANALYSES}

The collected data describing the frequency of visits of the hummingbird species, were analyzed using a Factorial Analysis of Variance (ANOVAF) to determine if there was a significant difference $(p<0.05)$ between the visitation rates of each species and the number of visits that occurred in each of the 10 foraging observation periods of each species, as well as between species, during the day. Posteriori comparisons were conducted using the Tukey HSD test. Statistical analyses were performed using the program Statistica for Windows, version 7.2 (StatSoft Inc., Tulsa, OK, USA).

\section{RESULTS AND DISCUSSION}

\section{REPRODUCTIVE PHENOLOGY}

Of the $10 \mathrm{D}$. pinnata individuals monitored, eight flowered (80\%) and five -showed formation of fruits (50\%). Teixeira and Ranga (2004) have cited the small number of specimens of fruiting $D$. pinnata that are herbalized in scientific collections, which could indicate a relatively low fruiting rate for this species. The authors argued that this factor, in addition to its restricted distribution, render this plant a rare species. The flowering occurred in a synchronized manner between December 2010 and March 2011, with individuals presenting 
flowers in each inflorescence for close to one month. The fruiting took place between April and June 2011 (Table I). Dahlstedtia pinnata exhibited cylindrical inflorescences with large flowers (Figure 1) and other characteristics typically observed in ornithophilous plants (Faegri and Van der Pijl 1979), such as pink, tubular corollas and sepals, with its seeds forming dehiscent pods that are greenish-colored during formation and have a withered appearance close to their openings.

TABLE I

Reproductive phenology of 10 individuals of the plant Dahlstedtia pinnata monitored between August 2010 and August 2011 in Pedra Branca State Park in Rio de Janeiro. $F=$ flowers, Frf = fruits in formation, $F r=$ fruits formed, - = absence of reproductive structures.

\begin{tabular}{|c|c|c|c|c|c|c|c|c|c|c|c|c|}
\hline \multirow[b]{2}{*}{ Individual } & \multicolumn{7}{|c|}{2011} & \multicolumn{5}{|c|}{2010} \\
\hline & Jan & Feb & Mar & Apr & May & Jun & Jul & Aug & Sep & Oct & Nov & Dec \\
\hline 1 & $\mathrm{~F}$ & $\mathrm{~F}$ & Frf & Frf/Fr & $\mathrm{Fr}$ & - & - & - & - & - & - & $\mathrm{F}$ \\
\hline 2 & $\mathrm{~F}$ & F & - & - & - & - & - & - & - & - & - & $\mathrm{F}$ \\
\hline 3 & $\mathrm{~F}$ & $\mathrm{~F}$ & - & - & - & - & - & - & - & - & - & $\mathrm{F}$ \\
\hline 4 & $\mathrm{~F}$ & $\mathrm{~F}$ & Frf & $\mathrm{Fr}$ & - & - & - & - & - & - & - & $\mathrm{F}$ \\
\hline 5 & $\mathrm{~F}$ & $\mathrm{~F}$ & $\mathrm{~F}$ & Frf & Frf/Fr & $\mathrm{Fr}$ & - & - & - & - & - & - \\
\hline 6 & $\mathrm{~F}$ & $\mathrm{~F}$ & Frf & Fr & Fr & - & - & - & - & - & - & $\mathrm{F}$ \\
\hline 7 & - & - & - & - & - & - & - & - & - & - & - & - \\
\hline 8 & $\mathrm{~F}$ & $\mathrm{~F}$ & $\mathrm{~F}$ & Frf & Frf/Fr & - & - & - & - & - & - & - \\
\hline 9 & - & - & - & - & - & - & - & - & - & - & - & - \\
\hline 10 & $\mathrm{~F}$ & $\mathrm{~F}$ & - & - & - & - & - & - & - & - & - & $\mathrm{F}$ \\
\hline
\end{tabular}

\section{FLOWER VISITORS}

Dahlstedtia pinnata was visited by five hummingbird species (Figure 1): The Phaethornithinae Ramphodon naevius (Dumont, 1818), Phaethornis pretrei (Lesson \& Delattre, 1839), Phaethornis ruber (Linnaeus, 1758), and the Trochilinae Amazilia fimbriata (Gmelin, 1788) and Thalurania glaucopis females (Gmelin, 1788). It is noteworthy that $R$. naevius and also D. pinnata, visited by this bird, are both endemic species to the Atlantic forest, and this hummingbird is globally categorized as Near Threatened (IUCN 2011). This hummingbird is known for pollinating diverse ornithophilous species in this southeastern Brazilian biome (Buzato et al. 2000, Sazima et al. 1995). Its foraging areas can include the understory as well as the forest canopy (Rocca and Sazima 2008).

\section{LEGITIMACY OF VISITS}

The only legitimate visits to flowers of $D$. pinnata were performed by species of the subfamily
Phaethornithinae; however, P. ruber also made illegitimate visits that totaled $78 \%$ of all visits recorded $(n=337)$ (Table II). While commonly associated with a negative effect on plant reproduction, flower thieving or robbing behaviors (Inouye 1980) can also have no effect or even a positive effect on plant reproduction by interfering in the visiting rate and behavior of effective pollinators (Maloof and Inouye 2000, Richardson 2004, Hargreaves et al. 2009). On the other hand, flowers damaged by flower thieves can become less attractive to pollinators than nondamaged flowers (Miller and Travis 1996, Ashman and King 2005, González-Gómez and Valdivia 2005). Until today, the effect of illegitimate visitors in the reproduction of $D$. pinnata remains unknown for science. The literature mentions that visitation by Phaethornithinae is linked to monocot species, while visits by Trochilinae are linked to dicots (Feinsinger and Colwell 1978). The observations of hummingbirds and D. pinnata in the present study were not consistent with this pattern. 

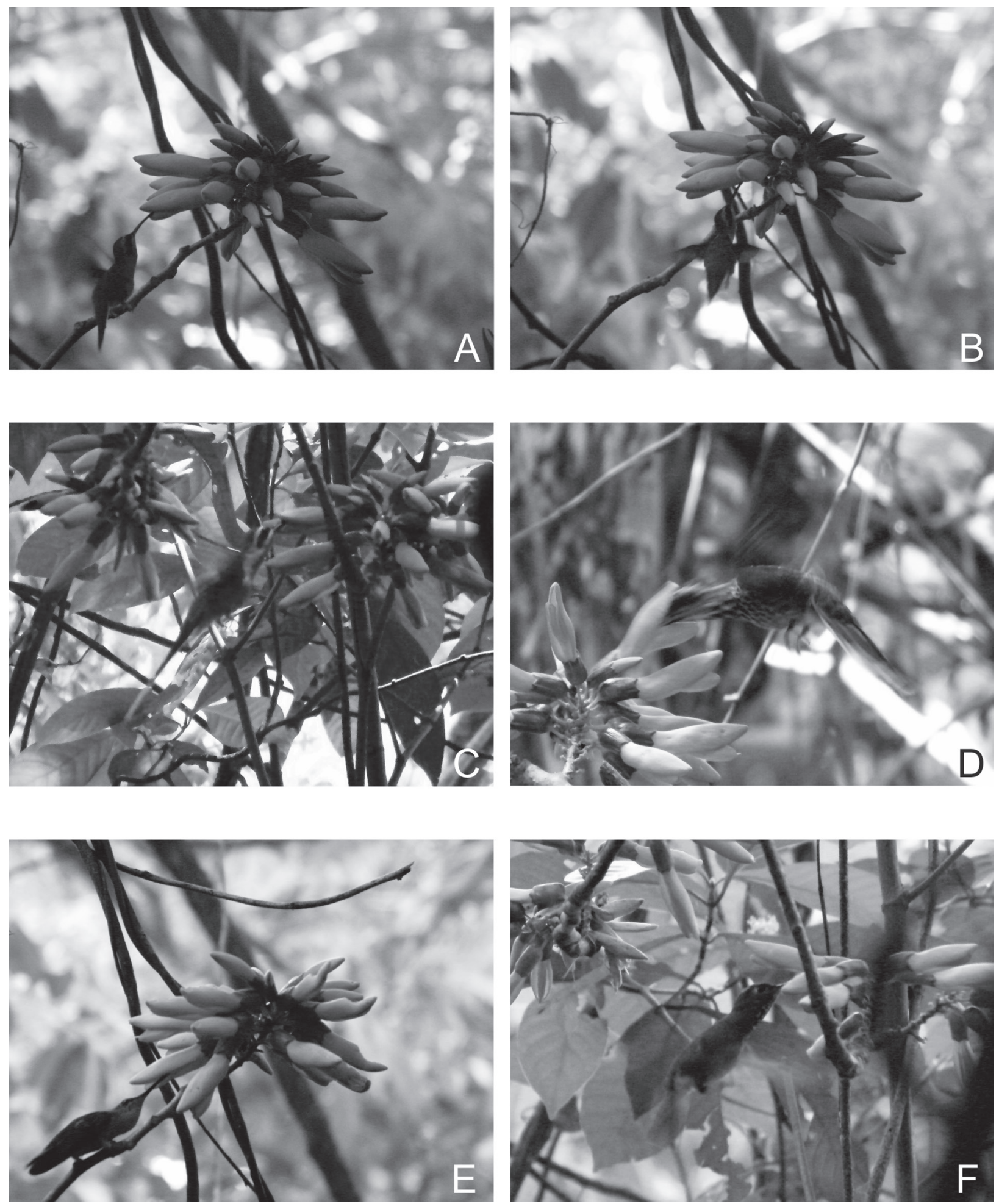

Figure 1 - Flower visitors of 10 individuals of the plant Dahlstedtia pinnata monitored between August 2010 and August 2011, in Pedra Branca State Park, Rio de Janeiro. a) Legitimate visits by Phaethornis ruber; b) Illegitimate visits by P. ruber; c) Legitimate visits by P. pretrei; d) Legitimate visits by Ramphodon naevius; e) Illegitimate visits during landing by Thalurania glaucopis females; f) Illegitimate visits by Amazilia fimbriata. Photos: Caio Missagia. 


\section{FORAGING BEHAVIOR}

Phaethornis pretrei was observed in a few agonistic interactions and successfully displaced $P$. ruber $(\mathrm{N}=3)$. This happened in casual encounters, which was characterized by non-territorial behavior (according to Feinsinger and Colwell 1978) (Table II). Phaethornis pretrei exhibited the lowest visitation rate $(\mathrm{T}=0.36)$, making only legitimate visits, always during flight and with brisk head movements that visibly left deposits of pollen at the frond and base of the hummingbird's beak.
Ramphodon naevius presented intraspecific and interspecific territorial behaviors, remaining at the inflorescences for long periods of time, and displaced other individuals of the same species $(\mathrm{N}=12)$, as well as individuals of $P$. pretrei $(\mathrm{N}=1), P$. ruber $(\mathrm{N}=3)$, and $A$. fimbriata $(\mathrm{N}=2)$ that approached the flowers. Although this species is known to be aggressive during rounds of trapline foraging (Sazima et al. 1995), its behavior observed in the present study conforms to that of territorial behavior, even though this behavior was only apparent during a

TABLE II

Number of registered visits ( $\mathrm{n}=1131)$, visitation rate (number of visits/hour $(0 \mathrm{h50m}$ of each hour)), type of visit, foraging behavior, and body weight of the flower-visiting hummingbirds in 10 individuals of the plant Dahlstedtia pinnata (Benth.) Malme. monitored between August 2010 and August 2011, in Pedra Branca State Park, Rio de Janeiro.

\begin{tabular}{cccccc}
\hline & \multicolumn{5}{c}{ Species } \\
\cline { 2 - 6 } & Phaethornis ruber & P. pretrei & $\begin{array}{c}\text { Ramphodon } \\
\text { naevius }\end{array}$ & $\begin{array}{c}\text { Thalurania } \\
\text { glaucopis }\end{array}$ & Amazilia fimbriata \\
\hline Number of visits & 337 & 164 & 220 & 240 & 170 \\
Rate of visits & 0.74 & 0.36 & 0.48 & 0.55 & 0.37 \\
Legitimacy of visits & Legitimate/Illegitimate & Legitimate (100\%) & Legitimate (100\%) & Illegitimate & Illegitimate \\
(percentage) & $(100 \% / 78 \%)$ & Trapliner & Territorial & Trapliner & $(100 \%)$ \\
Foraging behavior & Territorial & 5.6 & 7.9 & 4.8 & Trapliner \\
Body weight $(\mathrm{g})$ & 2.4 & & & 4.9 \\
\hline
\end{tabular}

few moments of the day (Feinsinger and Colwell 1978, Wolf 1978). Ramphodon naevius presented an intermediary visitation rate in relation to the other hummingbirds $(\mathrm{T}=0.48)$, visiting flowers legitimately and only in flight, making small rounds and perching on branches very close to the inflorescence. Several times during these visits, the hummingbird emitted vocalizations and rubbed its beak over its feathers, apparently cleaning itself (Sick 1997). These vocalizations appeared to repel other visiting hummingbirds (and potential pollinators). Ramphodon naevius is considered a large hummingbird. Thus, much like P. pretrei, placing its head in the flower left traces of pollen at the frond and base of the bird's beak.

Phaethornis ruber exhibited frequent intraspecific territorial behavior $(\mathrm{N}=65)$, ignoring the other hummingbird species (Table III), which could possibly be explained by their small body size when compared to that of other species (Brown et al. 1978). This species presented the highest visitation rate $(\mathrm{T}=0.74)$ and its visits were made in flight, at times hovering with one or both legs on another flower or a thin branch for support. During illegitimate visits, it inserted its beak in the space between the flower cup and corolla of $D$. pinnata in order to reach the nectar (Figure 1b).

Amazilia fimbriata showed trapline foraging and was subordinated in all interactions with other hummingbirds observed during the present study (Table III). This species showed the second lowest visitation rate $(\mathrm{T}=0.37)$, making illegitimate visits, only in flight, and thieving the flowers until having visited all of them. In this exploration of the $D$. 
pinnata flower, A. fimbriata inserted its beak into the space between the flower cup and corolla in order to reach the nectar.

TABLE III

Agonistic interactions between species of flower-visiting hummingbirds in 10 individuals of the plant Dahlstedtia pinnata monitored between August 2010 and August 2011 in Pedra Branca State Park, Rio de Janeiro.

\begin{tabular}{ccccc}
\hline & \multicolumn{4}{c}{ Aggressors species } \\
\cline { 2 - 5 } Subordinated species & P. ruber & P. pretrei & R. naevius & $\sum$ \\
\hline Phaethornis ruber & 65 & 3 & 3 & $\mathbf{7 1}$ \\
P. pretrei & 0 & 0 & 1 & $\mathbf{1}$ \\
Ramphodon naevius & 0 & 0 & 12 & $\mathbf{1 2}$ \\
Amazilia fimbriata & 0 & 0 & 2 & $\mathbf{2}$ \\
Thalurania glaucopis & 0 & 0 & 1 & $\mathbf{1}$ \\
$\sum$ & $\mathbf{6 5}$ & $\mathbf{3}$ & $\mathbf{1 9}$ & \\
\hline
\end{tabular}

Thalurania glaucopis females also showed trapline foraging and were subordinated in all their interactions with other hummingbirds observed in the present study. This hummingbird obtained the second highest visitation rate $(\mathrm{T}=0.55)$, although only visited the flowers illegitimately, but both in flight and while landed. Individuals of this species perched themselves on the plant stem, and either used their wings to help them maintain balance or supported themselves only on their legs. Nectar was accessed in a similar fashion to that of $A$. fimbriata. While males were sighted in proximity to D. pinnata flowers, there were no male visits recorded, consistent with observations by Missagia and Verçoza (2011).

Ramphodon naevius, which proved dominant in relation to the other species observed, possesses a body weight greater than that of its subordinates (Table II), which could explain this dominance. Differences in body sizes among species reduce interspecific competition by influencing the establishment of the dominance hierarchy between species (Loss and Silva 2005, Antunes 2003, Cotton 1998, Piratelli 1993, Brown et al. 1978, Feinsinger 1978). The aggressiveness of smaller hummingbirds (as observed in the case of $P$. ruber) could ensure their dominance in relation to other, even smaller flower visitors, such as small insects (Cotton 1998, Brown et al. 1978).

The Phaethornithinae hummingbirds are known for trapline foraging (Feinsinger and Colwell 1978), although $R$. naevius presented territorial behavior. This kind of behavior in Phaethornithinae is not common and corroborates the idea that a dominance hierarchy could be established according to the importance of a resource for a particular species, among other reasons, like body mass or aggressiveness of the species (Brown et al. 1978, Feinsinger 1978, Feinsinger and Colwell 1978). In this case, D. pinnata could be such an important resource for $R$. naevius that this bird needs to defend the resource against other visitors.

RESOURCE SHARING AMONG HUMmingBIRDS

Hummingbirds presented temporal sharing in the utilization of the floral resource, as indicated by the results of the ANOVAF analyses, which showed a significant difference between the visitation rates of $P$. ruber and all other species, as well as between $T$. glaucopis and other species except for $R$. naevius (Table IV). The results also showed a significant difference between the foraging schedules of the species during the course of the day (Figure 2).

The hummingbird species that made legitimate visits, did so at specific times of the morning, with $P$. pretrei showing a greater activity between 06:00 and 07:50, R. naevius between 08:00 and 09:50, and $P$. ruber between 10:00 and 10:50; whereas the species making illegitimate visits foraged with greater frequency in the absence of legitimate visitor activity or during the activity of $P$. ruber. Amazilia fimbriata presented a greater amount of activity between 10:00 and 13:50, and T. glaucopis between 10:00 and 10:50 and between 13:00 and 13:50. Similar behavior was observed by Antunes (2003) in flowers of Eucalyptus sp. (Myrtaceae), where dominant hummingbird species visited most frequently during the morning and subordinate species visited most frequently during the afternoon. 


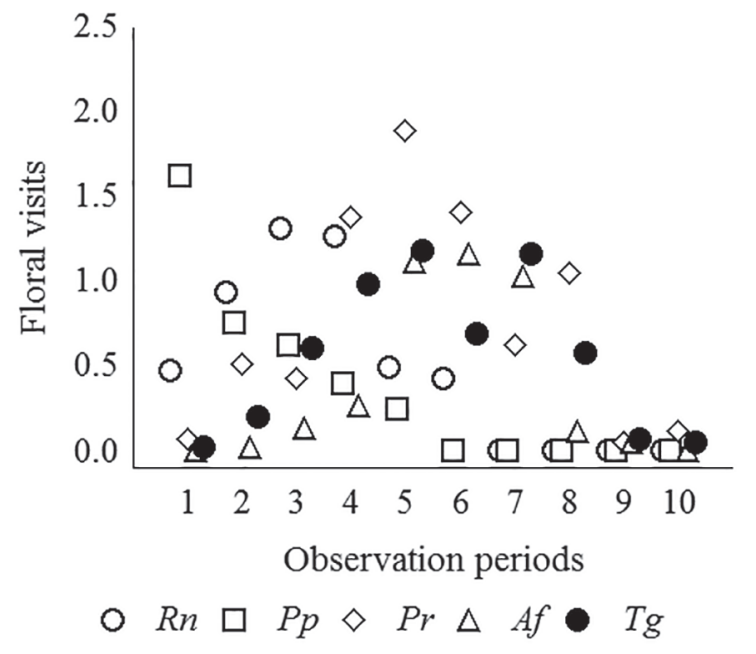

Figure 2 - Graphic results of the frequency of five hummingbird species during ten 50-minute periods of observation of flowers in 10 individuals of the plant Dahlstedtia pinnata monitored between August 2010 and August 2011, in Pedra Branca State Park, Rio de Janeiro. $\mathrm{Rn}=$ Ramphodon naevius, $\mathrm{Pp}=$ Phaethornis pretrei, $\mathrm{Pr}=$ P. ruber, Af $=$ Amazilia fimbriata, $\mathrm{Tg}=$ Thalurania glaucopis.

Sharing resource is a dynamic equilibrium that varies together with the number of species and individuals, as well as each species' aggressiveness, in such a way that even small differences in foraging behavior of the hummingbirds could contribute to or reinforce such sharing (Cotton 1998, Carpenter et al. 1983, Stiles and Wolf 1970). It is possible that the legitimate visitors foraged during hours of the greatest secretion of nectar. If this were the case, we could suppose that the greatest secretion of nectar coincides with the activity of $R$. naevius, which is a hypothesis that needs to be tested.

The results of the present study indicate that Dahlstedtia pinnata is ornithophily in terms of pollination syndrome, with its legitimate visitors restricted to hummingbirds of the subfamily Phaethornithinae. The body size of these birds appears to be an important factor for the sharing of the floral resource (nectar), which could explain the dominance of $R$. naevius in relation to other hummingbird species that are smaller in size.
TABLE IV

Results of the Factorial Analysis of Variance (ANOVAF) in the visiting frequency of five hummingbird species during ten 50-minute periods of observation of flowers in 10 individuals of the plant Dahlstedtia pinnata (Benth.) Malme. monitored between August 2010 and August 2011, in Pedra Branca State Park, Rio de Janeiro. d.f.: degrees of freedom; SS: sum of squares; MS: mean sum of squares; F: Fisher; P: probability. $\mathrm{Rn}=$ Ramphodon naevius, $\mathrm{Pp}=$ Phaethornis pretrei, $\mathrm{Pr}=$ P. ruber, $\mathrm{Af}=$ Amazilia fimbriata, Tg = Thalurania glaucopis female.

\begin{tabular}{cccccc}
\hline Effect & SS & d.f. & MS & F & P \\
\hline Species & 43 & 4 & 10.74 & 23.17 & $<0.01$ \\
$\begin{array}{c}\text { Observation periods } \\
\begin{array}{c}\text { Species/Observation } \\
\text { periods }\end{array}\end{array}$ & 202.3 & 9 & 22.47 & 48.48 & $<0.01$ \\
\hline \multicolumn{5}{c}{ Significance differences between species } \\
\hline Rn & Rn & Pp & Pr & Af & Tg \\
\cline { 2 - 6 } Rn & 0.12 & $<0.01$ & 0.28 & 0.76 \\
Pp & 0.12 & & $<0.01$ & 0.99 & $<0.01$ \\
Pr & $<0.01$ & $<0.01$ & & $<0.01$ & $<0.01$ \\
Af & 0.28 & 0.99 & $<0.01$ & & 0.01 \\
Tg & 0.76 & $<0.01$ & $<0.01$ & 0.01 & \\
\hline
\end{tabular}

\section{ACKNOWLEDGMENTS}

We would like to thank the Conselho Nacional de Desenvolvimento Científico e Tecnológico (CNPq) for the research grant provided to Maria Alice S. Alves (process 08792/2009-2). We also thank the Fundação Carlos Chagas Filho de Amparo à Pesquisa do Estado do Rio de Janeiro (FAPERJ) who also awarded a research grant to the third author (process E-26/102.837/2012) in addition to a scholarship for technical improvement to the first author (process E-26/101.033/2011) while writing this paper.

\section{RESUMO}

A proposta do presente estudo foi investigar a fenologia reprodutiva e a partilha de recurso floral (néctar) de Dahlstedtia pinnata (Benth.) Malme. (Fabaceae), endêmica de Mata Atlântica, entre beija-flores. Para a fenologia considerou-se a presença de estruturas reprodutivas nas plantas e para a partilha de recurso floral foi examinada a frequência de potenciais polinizadores e comportamentos de forrageamento. Este estudo foi conduzido no Parque 
Estadual da Pedra Branca, no estado do Rio de Janeiro, em floresta ombrófila densa, entre agosto de 2010 e agosto de 2011. A floração ocorreu entre dezembro de 2010 e março de 2011, e a frutificação entre abril e junho de 2011. Os horários de forrageamento dos beija-flores diferiram significativamente, com visitas legítimas às flores ocorrendo pela manhã, e ilegítimas no final da manhã e à tarde. Cinco espécies de beija-flores visitaram flores, três delas como visitantes legítimos: Phaethornis ruber, P. pretrei e Ramphodon naevius. Amazilia fimbriata e fềmeas de Thalurania glaucopis realizaram apenas visitas ilegítimas. Phaethornis ruber pilhou néctar (78\% de visitas ilegítimas, $\mathrm{n}=337$ ). Ramphodon naevius, com comportamento de forrageamento territorial e um tamanho corporal superior às demais espécies de beija-flores observadas, dominou as visitas florais. Isso sugere que $D$. pinnata é um recurso alimentar importante para essa ave endêmica de Mata Atlântica e globalmente categorizada como Quase Ameaçada.

Palavras-chave: pilhagem floral, comportamento de forrageamento, ornitofilia, polinização.

\section{REFERENCES}

ALTMANN SA. 1974. Observational study of behavior sampling methods. Behavior 49: 229-265.

ANTUNES AZ. 2003. Partilha de recurso de Eucalyptus sp. por beija flores e hierarquia de dominância em beija-flores (Aves: Trochilidae) no sudeste do Brasil. Ararajuba 11(1): 39-44.

ASHMAN TL AND King EA. 2005. Are flower-visiting ants mutualists or antagonists? A study in a gynodioecious wild strawberry. Am J Bot 92: 891-895.

BAWA KS. 1990. Plant-Pollinator Interactions in Tropical Rain Forests. Annu Rev Ecol Syst 21: 399-422.

Brown J, Willian A, Calder III and Codrig-Brown A. 1978. Correlates and consequences of body-size in nectarfeeding birds. Am Zool 14: 697-700.

Buzato S, Sazima M and Sazima I. 2000. Hummingbirdpollinated floras at three Atlantic forest sites. Biotropica 32: 824-841.

Carpenter Fl, Paton DC and Hixon MA. 1983. Weight gain and adjustment of feeding territory size in migrant hummingbirds. Proc Natl Acad Sc USA 80: 7259-7263.

COSTA NM AND SILVA JX. 2004. Geoprocessamento aplicado a planos de manejo: o caso do Parque Estadual da Pedra Branca, RJ. In: SILVA JX AND ZAINDAN RT (Eds), Geoprocessamento e análise Ambiental: aplicações. Rio de Janeiro: Bertrand Brasil, p. 67-114.
COTTON PA. 1998. Temporal partitioning of a floral resource by territorial hummingbirds. IBIS 140: 647-653.

DUNNING JR JB. 2008. CRC handbook of avian body masses. Florida: CRC Press, $371 \mathrm{p}$.

Faegri K And VAn Der PiJl L. 1979. Principles of Pollination Ecology. New York: Pergamon. 244 p.

FEINSINGER P. 1978. Ecological interactions between plants and hummingbirds in a tropical community. Ecol Monogr 48(3): 269-287.

FEINSINGER P AND COLWELL RK. 1978. Community organization among Neotropical nectar-feeding birds. Am Zool 18: 779-795.

Genini J, Galetti M and Morellato PC. 2009. Fruiting phenology of palms and trees in an Atlantic rainforest land-bridge island. Flora 204: 131-145.

GonZALEZ-Gomez PL AND VALDIVIA CE 2005. Direct and indirect effects of nectar robbing on the pollinating behavior of Patagona gigas (Trochilidae). Biotropica 37: 693-696.

HeITHaus ER. 1979. Community structure of neotropical flower visiting bees and wasps: diversity and phenology. Ecology 60(1): 190-202.

Hu S, DilChER DL, JARZEN DM AND TAYLOR DW. 2008. Early steps of angiosperm-pollinator coevolution. PNAS 105(1): 240-245.

IBGE. 1992. Manual Técnico da Vegetação Brasileira. Manuais Técnicos em Geociências, nº 1, Rio de Janeiro.

INOUYE DW. 1980. The terminology of floral larceny. Ecology 61: 1251-1253.

IUCN. 2011. The IUCN red list of threatened species.

KEARNS CA AND INOUYE D. 1993. Techniques for pollinations biologists. Colorado: University Press of Colorado, 579 p.

LEVIN DA AND ANDERSON W. 1970. Competition for Pollinators between Simultaneously Flowering Species. The American Naturalist 104(939): 455-467.

LINHART YB. 1973. Ecological and Behavioral Determinants of Pollen Dispersal in Hummingbird- Pollinated Heliconia. Am Nat 107: 511-523.

Loss ACC AND SiLvA AG. 2005. Comportamento de forrageio de aves nectarívoras de Santa Teresa - ES. Nat on line 3(2): 48-52.

Machado CG, Coelho AG, SANTANA CS AND Rodrigues M. 2007. Beija-flores e seus recursos florais em uma área de campo rupestre da Chapada Diamantina, Bahia. Rev Bras Ornit15(2): 267-279.

MALOOF JE AND INOUYE DW. 2000. Are nectar robbers cheaters or mutualists? Ecology 81: 2651-2661.

MendonçA LB AND AnJos L. 2005. Beija-flores (Aves, Trochilidae) e seus recursos florais em uma área urbana do Sul do Brasil. Rev Bras Ecol 22(1): 51-59.

Miller TE AND Travis J. 1996. The evolutionary role of indirect effects in communities. Ecology 77(15): 1329-1335.

Missagia CCC AND VERÇOZA FC. 2011. Fenologia reprodutiva, polinização e frutificação de Heliconia spathocircinata Aristeg. (Heliconiaceae) em trecho de Floresta Atlântica no município do Rio de Janeiro. Biotemas 24(3): 13-23. 
OLIVEIRA RR. 2005. As marcas do homem na floresta: história ambiental de um trecho urbano de Mata Atlântica. Rio de Janeiro: Editora PUC-Rio, 230 p.

PIACENTINI V AND VARASSIN IG. 2007. Interaction Network and the Relationships between Bromeliads and Hummingbirds in an Area of Secondary Atlantic Rain Forest in Southern Brazil. J Trop Ecol 23(6): 663-671.

PIRATELLI AJ. 1993. Comportamento alimentar de beija-flores em Inga spp. (Leguminosae, Mimosaceae) e Jacaratia spinosa (Caricaceae) em mata residual do sudeste brasileiro. IPEF 46: 43-51.

RAVEN PH, EVERT RF AND EICHHORN SE. 2007. Biologia Vegetal. Rio de Janeiro: Guanabara Koogan, 813 p.

RICHARDSON SC. 2004. Are nectar-robbers mutualists or antagonists? Oecologia 139: 246-254.

RICKLEFS RE. 2010. A economia da natureza. Rio de Janeiro: Guanabara Koogan, 522 p.

RocCA MA AND SAZIMA M. 2008. Ornithophilous canopy species in the Atlantic rain forest of southeastern Brazil. J Field Ornithol 79(2): 130-137.

SAZIMA I, Buzato S AND SAZIMA M. 1995. The saw-billed Hermit Ramphodon naevius and its flowers in southeastern Brasil. J Ornithol 136: 195-206.

SCHUCHMANN KL. 1999. Family Trochilidae (Hummingbirds) In: DEL HOYO J, ELLIOTT A and SARGATAL J (Eds), Handbook of the Birds of the World. Vol. 5. Barcelona: Lynx Edicions.
SICK H. 1997. Ornitologia brasileira. Rio de Janeiro: Editora Nova Fronteira, 912 p.

SMAC - Secretaria Municipal de Meio Ambiente. 1998. Informações especiais - Programa de Monitoramento dos Ecossistemas Costeiros Urbanos do Município do Rio de Janeiro, $48 \mathrm{p}$.

STILES FG AND WOLF LL. 1970. Hummingbird territoriality at a tropical flowering tree. The Auk 87: 467-491.

TALORA DC AND Morellato PC. 2000. Fenologia de espécies arbóreas em floresta de planície litorânea do sudeste do Brasil. Revta Brasil Bot 23(1): 13-26.

TEIXEIRA SP AND GABRIELLI AC. 2000. Anatomia do eixo vegetativo de Dahlstedtia pinnata (Benth.) Malme e D. pentaphylla (Taub.) Burkart (Leguminosae, Papilionoideae). Braz J Bot 23: 1-11.

TEIXEIRA SP AND RANGA NT. 2004, Biosystematics of the genus Dahlstedtia Malme (Leguminosae, Papilionoideae, Millettieae). Braz J Bot 27: 37-45.

VARASSIN IG AND SAZIMA M. 2000. Recurso de Bromeliaceae utilizados por beija-flores e borboletas no Sudeste do Brasil. Bol Mus Biol Mello Leitão 11/12: 57-70.

WOLF LL. 1978. Aggressive Social Organization in Nectarivorous Birds. Am Zool 18(4): 765-778.

WOLF LL AND HAINSWORTH FR. 1971. Time and Energy Budgets of Territorial Hummingbirds. Ecology 52(6): 980-988. 